\title{
Identification of Ancient Feather Fragments Found in Melting Alpine Ice Patches in Southern Yukon
}

\author{
CARLA J. DOVE,,$^{1,2}$ P. GREGORY HARE ${ }^{3}$ and MARCY HEACKER ${ }^{1}$
}

(Received 13 April 2004; accepted in revised form 22 June 2004)

\begin{abstract}
Twelve ancient artifacts or fragmented feather samples recovered from melting alpine ice patches in southern Yukon were analyzed in order to identify the species of birds associated with the ice patches or used on weapons recovered from these sites. The identification of bird species used by ancient hunters as long ago as $4500 \mathrm{BP}$ enhances our insight into the customs, culture, and sophistication of life at that time. Downy feather barbs were found on two samples and microscopically identified as duck (Anatidae) and falcon (Falconidae). Further examination and comparisons using museum specimens resulted in a total of six identifications: Anatidae, eagle (Aquila or Haliaeetus), gyrfalcon (Falco rusticolus), white-tailed ptarmigan (Lagopus leucurus), short-eared owl (Asio flammeus), and northern flicker (Colaptes auratus luteus). Three of the feather samples were complete enough to show apparent modification, or notching, along the feather shaft. The identification of non-game birds such as gyrfalcon and eagles, together with evidence of possible worked or notched feathers, indicates that as long as 4500 years ago, Subarctic hunters selected feathers not only for their utility in fletching, but also possibly for symbolic or decorative purposes.
\end{abstract}

Key words: Yukon ice patches, feather identification, archaeological artifacts, radiocarbon dates

RÉSUMÉ. On a analysé 12 anciens artefacts ou échantillons de fragments de plumes découverts dans le sud du Yukon lors de la fonte de plaques de glace alpine, afin d'identifier les espèces aviaires associées à ces plaques de glace ou utilisées sur les armes provenant de ces sites. L'identification des espèces aviaires utilisées par les anciens chasseurs à une époque aussi reculée que $4500 \mathrm{BP}$ nous permet de mieux comprendre les coutumes, la culture et le degré de sophistication de la vie à cette époque. On a trouvé des barbes duveteuses sur deux échantillons et l' analyse au microscope a révélé qu' elles appartenaient à un canard (anatidé) et à un faucon (falconidé). Un examen plus poussé et des comparaisons avec des spécimens présents dans des musées ont permis d'établir six provenances: anatidé, aigle (Aquila ou Haliaeetus), faucon gerfaut (Falco rusticolus), lagopède à queue blanche (Lagopus leucurus), hibou des marais (Asio flammeus) et pic flamboyant (Colaptes auratus luteus). Trois des échantillons de plumes étaient assez complets pour révéler des modifications apparentes ou encoches, le long de la tige de la plume. L'identification d'oiseaux non cynégétiques tels que le faucon gerfaut et les aigles, combinée avec la découverte de plumes encochées ou éventuellement travaillées, révèle qu'il y a 4500 ans, les chasseurs subarctiques sélectionnaient déjà les plumes non seulement dans un but utilitaire pour en faire des empennes de flèches, mais peut-être aussi à des fins symboliques ou d'ornementation.

Mots clés: plaques de glace dans le Yukon, identification de plumes, artefacts archéologiques, datation au radiocarbone

Traduit pour la revue Arctic par Nésida Loyer.

\section{INTRODUCTION}

Since 1997, the discovery of an abundance of ancient artifacts and biological remains in melting alpine ice patches in southern Yukon (Fig. 1) has sparked a variety of scientific interests ranging from anthropology to molecular biology (Kuzyk et al., 1999; Krajick, 2002; Farnell et al., 2004; Hare et al., 2004). The initial radiocarbon dates of these artifacts and associated organic material reflect a continuous biological record from approximately $8300 \mathrm{BP}$ (uncalibrated) to modern times (Farnell et al., 2000) and represent some of the oldest known organic artifacts discovered in North America. Organic artifacts are rarely preserved in archaeological sites except in special circumstances, such as waterlogged, frozen, or extremely dry sites. Because the ice patch artifacts have been naturally cryogenically preserved for centuries, tissue and other biological materials include higher-quality samples for study, less degraded than those found under normal circumstances.

The presence of whole birds (Krajick, 2002), feathers, and feather fletchings (the attachment of feathers to arrows) associated with the wooden weapon shafts recovered from these ice patches became apparent as soon as

\footnotetext{
${ }^{1}$ Smithsonian Institution, National Museum of Natural History, Department of Vertebrate Zoology, Room E-600 MRC 116, Washington, D.C. 20560, U.S.A.

${ }^{2}$ Corresponding author: dovec@ si.edu

${ }^{3}$ Heritage Branch, Government of Yukon, Box 2703, Whitehorse, Yukon Y1A 5H4, Canada

(C) The Arctic Institute of North America
} 


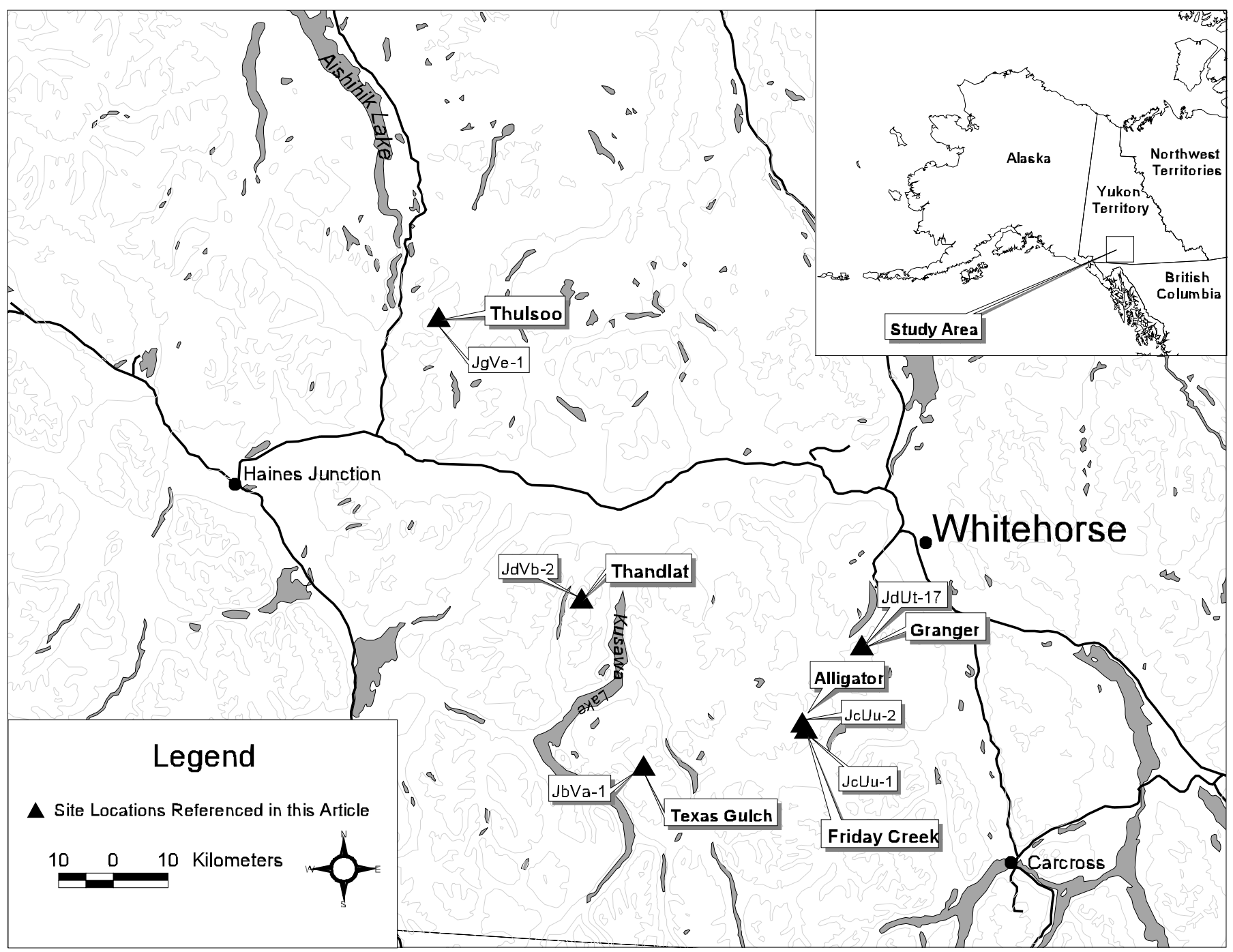

FIG. 1. Map of ice patch sites in southern Yukon, showing locations where items examined in this study were found.

scientists began examining the materials (Kuzyk et al., 1999; Krajick, 2002; Farnell et al., 2004). Because it is possible to identify birds from archaeological feather fragments and microscopic analysis (Hargrave, 1965; Messinger, 1965; Dove, 1998; Dove and Peurach, 2002; Rogers et al., 2002), we examined some of the feathers directly attached to or associated with these artifacts in order to document the species of birds used by these ancient peoples.

This study is part of ongoing research to describe and document the organic material used on these artifacts. All specimens included in this study were collected at alpine ice patches in southern Yukon (Fig. 1) between 1998 and 2002 by a variety of researchers and field assistants. Specimens are currently stored at the laboratories of the Cultural Services Branch of the Yukon Government. Radiocarbon dates for all recovered artifacts range from 8360 BP to 90 BP (Hare et al., 2004). Feathers from this study ranged in age from $4580 \mathrm{BP}$ to $190 \mathrm{BP}$ (several specimens are undated).

\section{METHODS}

Twelve catalogued artifacts or feather samples were examined in this study (Table 1). Because the feathers were heavily soiled and fragmented, initial examination involved removing minute samples of feather or featherlike filaments from specimens with microforceps for microscopic analysis before any cleaning procedures were performed. These samples were mounted on microslides and labeled with individual specimen field catalogue numbers. Microslide preparation followed methods described in Laybourne and Dove (1994), Dove (1998), and Rogers et al. (2002) for anthropological artifacts. Microslides were examined using a Reichert Diastar, comparison light microscope, and photographs were taken with a Polaroid DMC Ie, digital camera. Labeled microslides are stored at the Heritage Branch and associated with the artifacts from the ice patch collections. It was determined that five items contained large feather pieces, or enough individual feathers that a part of the sample could be subjected to washing and cleaning procedures. In this study, feathers were 
TABLE 1. Avian identifications from ancient feathers associated with artifacts of Yukon ice patches.

\begin{tabular}{|c|c|c|c|c|c|}
\hline Artifact Number & Avian Identification & Artifact Description & Washed & Radiocarbon Date & Location \\
\hline $\mathrm{JbVa}-1: 1 \mathrm{a}$ & $\begin{array}{l}\text { Eagle } \\
\text { (Aquila or Haliaeetus) }\end{array}$ & split flight feather & yes & $440 \pm 50 \mathrm{BP}$ & Texas Gulch IP \\
\hline JcUu-1:8 & unidentified & pennaceous flight feathers & no & $\mathrm{n} / \mathrm{a}$ & Friday IP \\
\hline JcUu-1:9 & unidentified & two pennaceous feather shafts attached to stick & no & $1250 \pm 40 \mathrm{BP}$ & Friday IP \\
\hline JcUu-2:1 & unidentified $^{1}$ & fragmented feathers & yes & $4580 \pm 70 \mathrm{BP}$ & Alligator IP \\
\hline JcUu-2:1c & $\begin{array}{l}\text { Northern flicker } \\
\text { (Colaptes auratus luteus) }\end{array}$ & $\begin{array}{l}\text { birch shaft with large feather rachis and small } \\
\text { yellow feather wrapped with sinew }\end{array}$ & no & $4580 \pm 70 \mathrm{BP}$ & Alligator IP \\
\hline $\mathrm{JcUu}-2: 2 \mathrm{~h}$ & Duck (Anatidae) ${ }^{1}$ & single primary feather & yes & $3900 \pm 70 \mathrm{BP}$ & Alligator IP \\
\hline JcUu-2:16 & unidentified & split feathers on spruce stick & no & $190 \pm 40 \mathrm{BP}$ & Alligator IP \\
\hline JcUu-2:22 & $\begin{array}{l}\text { White-tailed ptarmigan } \\
\text { (Lagopus leucurus) }^{1}\end{array}$ & one white feather and various other dark flight feathers & yes & $\mathrm{n} / \mathrm{a}$ & Alligator IP \\
\hline JcUu-2:24 & $\begin{array}{l}\text { Gyrfalcon } \\
\text { (Falco rusticolus) }\end{array}$ & a clump of approximately eight flight feathers & yes & $\mathrm{n} / \mathrm{a}$ & Alligator IP \\
\hline JdUt-17:3e & unidentified & large pennaceous feather attached to tip of artifact & no & $1840 \pm 40 \mathrm{BP}$ & Granger IP \\
\hline $\mathrm{JdVb}-2: 1$ & unidentified & small feather shafts wrapped in sinew on artifact & no & $4360 \pm 50 \mathrm{BP}$ & Thandlat IP \\
\hline $\mathrm{JgVe}-1: 11$ & $\begin{array}{l}\text { Short-eared owl } \\
\text { (Asio flammeus) }\end{array}$ & single flight feather & yes & $\mathrm{n} / \mathrm{a}$ & Thulsoo IP \\
\hline
\end{tabular}

${ }^{1}$ Notched feathers.

washed in a hot, mild soap (not detergent) solution with gentle hand agitation. Large pieces of mud and dirt were removed by hand from feathers during a hot water soaking phase. This soaking also helped the feathers regain their natural shape. Feathers were rinsed in several changes of clean water and gently dried with compressed air.

The feather identification technique involves both examining the microscopic variation in characters in the plumulaceous (downy) barbs that are located at the base of most contour feathers (Fig. 2) and comparing whole feathers or pieces of feathers to a museum collection of study skins. In this study, the unknown feather samples were compared with specimens from species of birds that occur in the Yukon Territory.

\section{RESULTS}

We identified six different bird species from the twelve feather fragments found associated with the ice patch samples (Table 1). Microscopic (downy) feather characters were found in samples from two items $(\mathrm{JcUu}-2: 2 \mathrm{~h}$, JcUu-2:24). Item JcUu-2:24 included approximately eight flight feathers (longest flight feather approximately $23 \mathrm{~cm}$ ) clumped together with mud and dirt. Downy barbs that were initially sampled from the base of these feathers had microscopic characters that consisted of very long barbules, many rounded nodes that were uniformly distributed along the barbule, and pigment at the nodes. These characters are
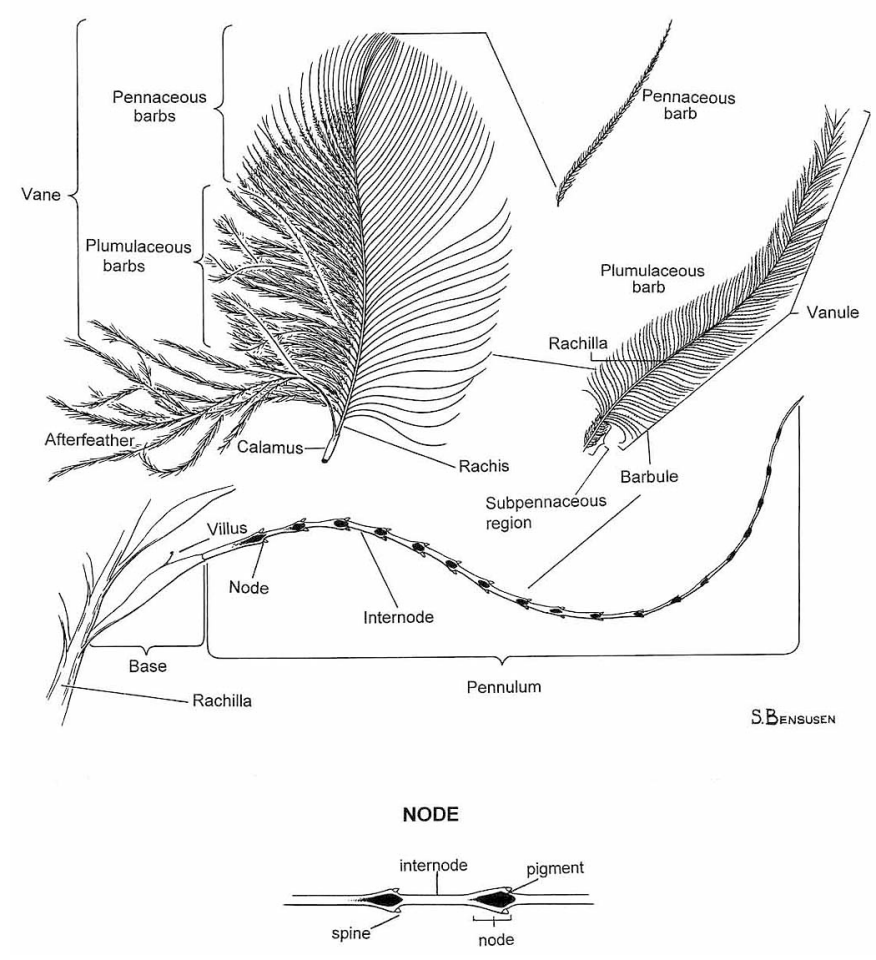

FIG. 2. Topography of a contour feather (modified from Laybourne et al., 1994, Fig. 1) showing plumulaceous (downy) barbs, which are important for microscopic analysis. The variation in the nodal morphology (below) of plumulaceous barbules aids in the microscopic identification of groups of birds from minute feather samples. 


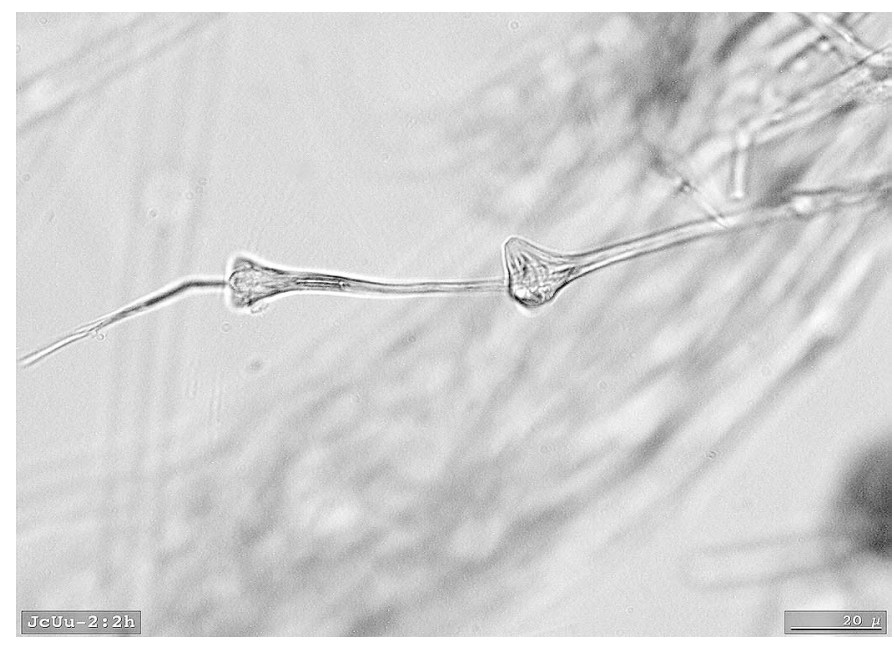

FIG. 3. Photomicrograph of plumulaceous (downy) feather sample from item JcUu-2:2h, showing diagnostic microscopic characters of triangular-shaped nodes typical of ducks (Anatidae).

typical of falcons (Falconidae). Item JcUu-2:2h was determined to be a type of duck (Anatidae) by the diagnostic microscopic characters of triangular shaped nodes on the distal portion of barbules (Fig. 3). After initial microscopic analysis resulted in two family-level identifications (falcon and duck), larger feather samples from these two items were subjected to washing procedures in hopes of discovering additional morphological characters, such as color, pattern or texture, to aid in species identifications. Amazingly, these feathers remained intact and reacted to the washing process much in the same way as modern-day feathers. Feathers from ice patch locations were not brittle and regained their natural shape and color once the mud and dirt had been properly removed. Because the falcon feather sample that was washed showed color and pattern (Fig. 4), it was compared to a series of museum specimens of Falconidae and determined to be an underwing covert from a gray plumaged gyrfalcon (Falco rusticolus). The duck feather did not contain diagnostic characters for species identification. Once the washing procedure was determined to be effective on these two feather samples, additional items were washed if sufficient material was available for whole-feather comparisons. Washings resulted in species identifications of northern flicker (Colaptes auratus luteus, item JcUu-2:1c), short-eared owl (Asio flammeus, item JgVe-1:11), and white-tailed ptarmigan (Lagopus leucurus, item JcUu-2:22). The ptarmigan feather did not match rock ptarmigan (Lagopus mutus) or willow ptarmigan (Lagopus lagopus) in size of feather, coloration of rachis, or morphology of the dorsal grooved rachis of the outer primary. Item JbVa-1:1a was identified as golden or bald eagle (Aquila or Haliaeetus) and did not contain diagnostic characters for species-level identification. This item consisted of a partial feather that was split longitudinally through the rachis. The feather was identified as eagle from its size, color, and the coarse texture of the pennaceous barbs. This feather fragment did

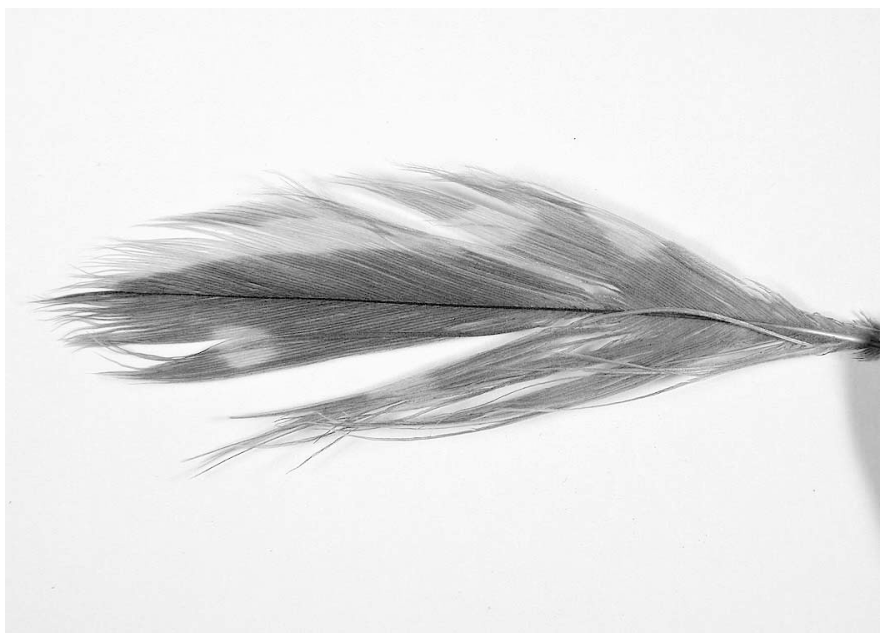

FIG. 4. A whole feather sample from item JcUu-2:24, showing the barring pattern that was revealed after the feather was subjected to cleaning procedures. This feather was identified as an underwing covert from a gray plumaged gyrfalcon (Falco rusticolus).

not match any other Yukon endemic species that have large brown feathers.

The northern flicker (Colaptes auratus luteus) partial feather was wrapped in sinew and attached to a birch weapon shaft (JcUu-2:1c). This feather was identified as a tail feather from the yellow-shafted race of this species, which generally ranges from central Alaska south to Montana (Moore, 1995).

Three of the washed feathers (Table 1) also exhibited some degree of modification. A notched or sawtooth pattern along the rachis (e.g., see Fig. 5) was possibly created by cutting the barbs perpendicular to the rachis at three or four points along the feather. The inner vane was notched on one unidentified feather (JcUu-2:1), the outer vane of the duck feather had four notches, and both vanes were notched on the white-tailed ptarmigan.

\section{DISCUSSION}

\section{Feather Identification}

Feather identification was achieved at the species level in this study because there was sufficient feather material available for examination and we were granted permission to use proper cleaning and restoration methods. Feather identification was aided by the excellent condition of these biological specimens, which had suffered little degradation over time. Barbs and barbules were sturdy and intact, color patterns were present, and feathers were durable and comparable to modern-day specimens. In a similar study (Dove and Peurach, 2002) conducted on mummified remains from Kagamil Island, Alaska, only a very small percentage of the species could be identified because proper cleaning and sampling methods were not allowed. Items that were not identifiable in the current study did not contain diagnostic feather characters or lacked sufficient 


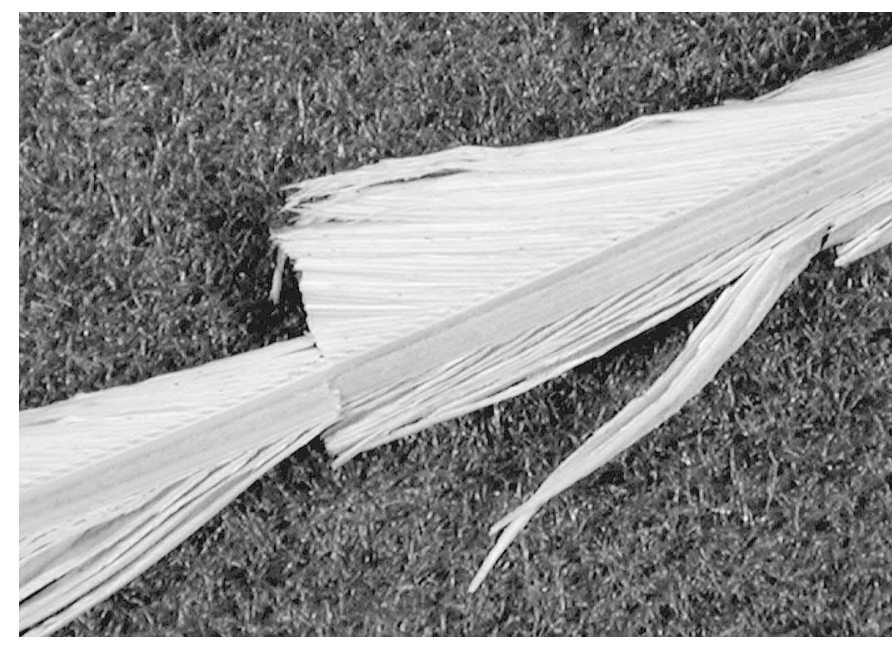

FIG. 5. Item JcUu-2:22, identified as a white-tailed ptarmigan (Lagopus leucurus) feather, showing the distinct notching or sawtooth pattern that was observed on some of the ice patch feathers.

feather material for examination (i.e., only the feather shaft was present).

\section{Traditional Use of Feathers}

Comparisons of feathers identified in this study with ethnographic information available for southern Yukon indicates considerable continuity over time in the selection of feathers used for fletching arrows or darts. This study provides evidence that in many cases feathers were being selected by native peoples of southern Yukon for reasons other than ease of availability. According to McClellan (1975), the most economically important birds for the people of southern Yukon were grouse, ptarmigan, geese, swans, and ducks; however, birds such as loons, owls, eagles, and ravens were noted as having supernatural or ceremonial significance (McClellan, 1975:167-168).

When making arrows, the Tagish Indians of southern Yukon were said to prefer eagle, duck, ptarmigan, and grouse feathers for fletchings (McClellan, 1975:283), while the neighboring Tlingit were said to use ptarmigan, hawk, and eagle feathers (Emmons, 1991:128).

Detailed information about arrow fletching in interior Alaska indicates that specific feathers may have been used for different types of game. According to Rev. David Salmon of Chalkyitsik, Alaska, eagle feathers were used on arrows intended for big game, hawk feathers on blunttipped arrows for small game, and raven feathers for waterfowl and aquatic animals (O'Brien, 1997). This suggests that the feathers of different species of birds may have different functional attributes that have not been explored in this study.

The single northern flicker feather on item $\mathrm{JcUu}-2: 1 \mathrm{c}$ is unusual because 1) the flicker has not been identified as an economically important or ceremonial species and 2) it is the only brightly colored feather identified in this study. This partial yellow tail feather was attached to the end of the weapon shaft together with at least one other larger unidentified brown feather. The flicker feather was not split at the rachis, was too small to have served any purpose in the fletching of the dart, and was not appropriately placed on the shaft to serve a fletching function. It is possible that it was used for decoration or identification of an individual's weapon.

Evidence that some of the feathers in this study were worked, or notched (JcUu-2:1, JcUu-2:2h, JcUu-2:22), needs to be further investigated to verify that the notching is not a characteristic caused by ice melt. There is ethnographic evidence of feather notching (cf. Cruikshank, 1991:108), but little indication that arrow fletchings were notched. The early Yukon Territory, Alaskan, and Canadian Arctic ethnology collections housed at the Smithsonian Institution's National Museum of Natural History were searched for evidence of the type of notching that was observed on the ice patch artifacts. Hundreds of feathered arrow shafts and atlatl darts had been collected during the mid to late 1800 s by a coterie of Smithsonian naturalists, including William Dall, Edward Nelson, Lucien Turner, and John Murdoch (Fitzhugh, 2002), and they remain in excellent condition. Only a small number (approximately 12) of the items in these large collections included notching or a saw-toothed pattern on feather fletchings. In the Smithsonian collections, notching ranged from many notches (up to 20) per individual feather to only one or two notches near the mid-section of the feather rachis. These notches were always located on one feather vane of whole, brown-colored feathers. Among the Yu' pik of southwestern Alaska, Nelson (1899:151-161) observed a definite preference for using cormorant feathers for fletching darts and arrows although he noted gyrfalcon feathers on arrow shafts and the practice of notching feathers. He refrained from discussing any functional or spiritual aspects of fletching practices. In describing the Inupiat collections derived from Point Barrow in 1881, Murdoch (1892:201) reported: "Generally, if not universally, the feathering was made of the feathers of some bird of prey, falcon, eagle, or raven, probably with some notion of giving to the arrow the death-dealing quality of the bird."

The use of non-game birds such as gyrfalcon, owls, and eagles, together with the evidence that some of these feathers may have been physically modified, suggests that fletchings were not simply utilitarian. Considerable effort and purpose were required to collect and prepare certain types of feathers for fletching, rather than using the feathers of species readily at hand. This study demonstrates that patterns of feather selection and curation outlined in the ethnographic material of southern Yukon are most probably deeply rooted in the ancient past. The remarkable preservation of the ice patch artifacts and biological specimens provides unprecedented insight into cultural continuities extending back many thousands of years. 


\section{ACKNOWLEDGEMENTS}

The Yukon Ice Patch Research Project is a cooperative research initiative involving numerous partners, including Yukon First Nations, government agencies, and academic institutions. Principal research partners include the Department of Environment and Department of Tourism and Culture, Government of Yukon; the Champagne-Aishihik First Nation; the Carcross-Tagish First Nation; the Kwanlin Dün First Nation, and the Kluane First Nation. Special thanks are extended to Art Johns, Carcross-Tagish First Nation, for discussions on feathers used for fletchings, and to Valery Monahan and Cathy Ritchie, for conservation services on artifacts transported to Washington, D.C.

All feather identifications were made using the bird collections at the National Museum of Natural History, Smithsonian Institution. Stephen Loring, Smithsonian Institution, Department of Anthropology, kindly showed us the notched featherwork in the anthropological collections and provided comments on an early version of the manuscript. The Robert Bateman Research Fund supported travel to report these research results at the 31st Annual Alaska Anthropological Association Conference in Whitehorse, Yukon. Peter Stettenheim and Pepper Trail provided helpful reviews of the final manuscript.

\section{REFERENCES}

CRUIKSHANK, J. 1991. Dan Dha Ts'edenintth'e Reading voices: Oral and written interpretations of the Yukon's past. Vancouver and Toronto: Douglas and McIntyre.

DOVE, C.J. 1998. Feather evidence helps clarify locality of anthropological artifacts in the Museum of Mankind. Pacific Studies 21(3):73-84.

DOVE, C.J., and PEURACH, S. 2002. Microscopic analysis of feather and hair fragments associated with human mummified remains from Kagamil Island, Alaska. In: Frohlich, B., Harper, A.B., and Gilberg, R., eds. To the Aleutians and beyond: The anthropology of William S. Laughlin. Ethnographical Series, Vol. 20. Copenhagen: Department of Ethnography, The National Museum of Denmark. 51-61.

EMMONS, G.T. 1991. The Tlingit Indians. Edited with additions by Frederica de Laguna and a biography by Jean Low. Anthropological Papers of the American Museum of Natural History 70. Seattle: University of Washington Press.

FARNELL, R.S., HARE, P.G., GOTTHARDT, R.M., BLAKE, E., JOE, L., STRAND, D., and GREER, S. 2000. Southern Yukon alpine ice patches: Climate change records, caribou history, ancient hunters and much more. Published Abstract, Arctic Science 2000 - Crossing Borders: Science and Community, 2124 September 2000. Whitehorse, Yukon: American Association for the Advancement of Science and the Yukon Science Institute.
FARNELL, R., HARE, P.G., BLAKE, E., BOWYER, V., SCHWEGER, C., GREER, S., and GOTTHARDT, R. 2004. Multidisciplinary investigations of alpine ice patches in Southwest Yukon, Canada: Paleoenvironmental and paleobiological investigations. Arctic 57(3):247-259.

FITZHUGH, W.F. 2002. Origins of museum anthropology at the Smithsonian Institution and beyond. In: Merrill, W., and Goddard, I., eds. Anthropology, history, and American Indians: Essays in honor of William Curtis Sturtevant. Smithsonian Contributions to Anthropology 44. Washington, D.C.: Smithsonian Institution. $179-200$.

HARE, P.G., GREER, S., GOTTHARDT, R., FARNELL, R., BOWYER, V., SCHWEGER, C., and STRAND, D. 2004. Ethnographic and archaeological investigations of alpine ice patches in Southwest Yukon, Canada. Arctic 57(3):260-272.

HARGRAVE, L. 1965. Identification of feather fragments by microstudies. American Antiquity 31:202-205.

KRAJICK, K. 2002. Melting glaciers release ancient relics. News Focus, Science 296:454-456.

KUZYK, G.W., RUSSELL, D.E., FARNELL, R.S., GOTTHARDT, R.M.,HARE, P.G., and BLAKE, E. 1999. In pursuit of prehistoric caribou on Thandlät, southern Yukon. Arctic 52(2):214-219.

LAYBOURNE, R.C., and DOVE, C.J. 1994. Preparation of birdstrike remains for identification. In: Proceedings and Working Papers of the Bird Strike Committee Meeting, 29 August-2 September, Vienna, Austria. 531-534.

LAYBOURNE, R.C., DEEDRICK, D., and HUEBER, F. 1994. Feather in amber is earliest New World fossil of Picidae. Wilson Bulletin 106(1): 18-25.

McCLELLAN, C. 1975. My old people say: An ethnographic survey of southern Yukon Territory. Publications in Ethnology 6. Ottawa: National Museum of Man.

MESSINGER, N.G. 1965. Methods used for identification of feather remains from Wetherhill Mesa. American Antiquity 31:206-215.

MOORE, W.S. 1995. Northern flicker. In: Poole, A., Stettenheim, P., and Gill, F., eds. The birds of North America 166. Philadelphia: Academy of Natural Sciences and Washington, D.C.: American Ornithologists' Union. 27 p.

MURDOCH, J. 1892. Ethnological results of the Point Barrow Expedition. 9th Annual Report of the Bureau of Ethnology 1887-1888. Washington, D.C.: Government Printing Office.

NELSON, E.W. 1899. The Eskimo about Bering Strait. 18th Annual Report of the Bureau of American Ethnology 1896-97. Washington, D.C.: Government Printing Office.

O'BRIEN, T.A. 1997. Athabaskan implements from the skin house days as related by Reverend David Salmon. Master's thesis, University of Alaska, Fairbanks.

ROGERS, J.D., DOVE, C.J., HEACKER, M., and GRAVES, G. 2002. Identification of feathers in textiles from the Craig Mound at Spiro, Oklahoma. Southeastern Archaeology 21(2):245251. 